\title{
Flexural Test for a Monolithic Holed Web Prestressed Concrete (HWPC) Girder
}

\author{
Man-Yop Han, ${ }^{1)}$ Kyung-Suk Jin, ${ }^{1)}$ and Sok-Hwan Choi ${ }^{2)}$
}

(Received March 11, 2010, Revised October 3, 2010, Accepted November 30, 2010)

\begin{abstract}
Prestressed concrete (PSC) I-type girders have been used for span length around up to $40 \mathrm{~m}$ in domestic region. PSC girders are very cost effective girder type and extending their lengths more than $50 \mathrm{~m}$ will bring large benefit in cost. A new design method was proposed by combining two notable design concept in order to extend the applicable span length in this study. First of all, several numbers of openings was introduced in the girder web, and half of the anchorage devices were moved into the openings. In this way, large compressive stress developed at end zone was reduced, and the portion of design load coming from selfweight was reduced as well. Secondly, prestressing force was introduced in the girder not once at the initial stage, but through multiple loading stages. A full scale girder with the length of $50 \mathrm{~m}$ with the girder depth of $2 \mathrm{~m}$ was fabricated, and a flexural test was conducted in order to verify the performance of newly developed girder. Test results showed that the new holed web design concept can provide a way to design girders longer than 50 meters with the girder height of $2 \mathrm{~m}$.
\end{abstract}

Keywords: HWPC, holed web girder, incrementally prestressed concrete girder, PSC, bridge girder.

\section{Introduction}

PSC I-type girders have been one of the most popular structural forms for the superstructures of bridges due to low construction cost and maintenance fee. But their span lengths used in Korea have been limited within the maximum range of $40 \sim 45 \mathrm{~m}$. The factor which determines the maximum girder length is the allowable stresses in concrete, which should be satisfied at every part in the concrete member for all individual prestressing and loading stages.

Bulb-T type PSC girders have been developed and successfully applied to achieve the span length of more than $50 \mathrm{~m}$ in many countries. $^{1-7}$ Bulb-T type girders, nonetheless, could not be easily adapted to the Korean market. It is mainly because the quality of concrete at construction site cannot be easily assured, and also when girders are manufactured at plants for quality control, they cannot be delivered to the site due to difficulties in transportation. Maximum length and weight of trucks allowed on roadways are given as $17 \mathrm{~m}$ and $400 \mathrm{kN}$, respectively, by the traffic law to protect roads.

Specifications for prestressed concrete construction impose certain limitations on stresses in the concrete at particular stages, such as while tensioning the prestressing steels, immediately after transfer of prestress force to the concrete, and at full service load. These stress limits are intended to avoid damage to the member during

\footnotetext{
${ }^{1)}$ KCI Member, Dept. of Civil and Trnsp. Engr., Ajou University, Suwon 443-749 Korea.

${ }^{2)}$ KCI Member, Dept. of Civil and Environ. Engr., Kookmin University, Seoul 136-702, Korea. Email: shchoi@kookmin.ac.kr. Copyright (c) 2010, Korea Concrete Institute. All rights reserved, including the making of copies without the written permission of the copyright proprietors.
}

construction, and to insure serviceability by indirectly limiting deflection and crack width. Stress limit specifications often provide the starting point in selecting the dimensions for PSC members. The loads such as self-weight of girder, weight of deck slab, additional dead loads, and live loads are applied to the girders through different loading sequence in actual structures. Instead of one time application, when the prestress force is introduced in the girder step by step as construction proceeds, either larger amount of prestress force can be introduced or more efficient girder dimension can be adopted. This prestressing method is called incremental prestressing. 8,9

In addition to the incremental prestressing, a method to distribute the location of anchorage devices will be proposed in this study. For post-tensioned girders with mechanical anchorages, the load is applied at the end face, and heavy longitudinal compressive stress develops right under the anchorage plate. Large principal compressive stress accompanied by significant principal tensile stress acting in the perpendicular direction produce longitudinal cracking in the end zone along the axis of prestressing force. Even though, in many post-tensioned prestressed girders, end blocks are provided having width equal to the narrower of the top or bottom flange width, it has been reported that girders with rectangular end blocks develop higher vertical tension than do otherwise identical girders without them. ${ }^{10}$ Nevertheless, end blocks have been installed to provide room for the anchorage devices. In addition, they provide greater bearing area to carry the high compression load at the anchorage, and it is helpful in avoiding splitting failure immediately under the anchorage plate, where, otherwise, stress tends to cause diagonal cracks emanating from the corners of the plate. ${ }^{11}$ Several numbers of holes are made in the girder web and about half of the anchorages are moved into 
the holes in this study. As a consequence, the compressive stress at both girder ends reduce dramatically and room for end anchorages is large enough not to require end blocks.

Other benefits including reduction of self-weight will be described in details in a section follows. A full-size holed web prestressed concrete girder was designed, manufactured, and tested. Design details and flexural and shear performance of the girder are presented in this paper.

\section{Incremental prestressing method}

Prestressing force which is large enough to compensate the total external loads including all extra dead loads and total live load cannot be implemented in the girder at the initial loading stage since tensile stresses which are larger than the allowable stress of concrete should not be developed at the top of the girder. This limitation can be overcome using multistage prestressing. ${ }^{8,9}$ A significant reduction of girder height and the increase of girder length can be achieved by applying the prestress force incrementally according to the increase of load imposed on the girder. In this method, prestressing force is partially applied at the first or initial stage, and compensates only self-weight of the girder and deck slab. After the deck slab concrete was cast and hardened, the whole section can resist the flexural moment through composite action. The second prestressing force which compensates the total design loads is then applied. This incremental prestressing maximizes the prestressing force that can be applied to the member.

Figure 1 illustrates the stress distributions in the girder through the incremental prestressing procedure at different loading stages. Initial prestressing is applied when there exits only self-weight of the girder, and the stress distributions at this stage can be shown as line (1), and it becomes line (2) when slab concrete is poured on the girder. Once the slab concrete has been hardened, girder and slab show a composite action. Additional secondary prestressing will be applied after slab concrete hardens, then the stress distribution will be changed. If additional dead and live loads are applied, top and bottom stresses become line (3). When the deck slab concrete has not been hardened enough for composite action, stress state is given as line (4). After the deck slab concrete has been hardened, all loads applied subsequently cause flexure about the composite centroid, and line (5) represents the stress state. When it is assumed that the entire prestressing loss occurs before the full service stage, line (6) represents the stress state. When full service loads are applied the stress distribution becomes line (7). Detailed information for this approach can be found in another publication. ${ }^{9}$

One important feature in the incrementally prestressing girder is its self-strengthening function. In other words, some of the prestressing steels can be left as unbonded state and they can be pulled out again any time when required. This function will be useful when the girder is sagged due to certain reasons in the future. Comparing with other concrete girder types developed so far, girders based on incremental prestressing concept can be longer by $20-30 \%$. The comparison group includes NEBT, ${ }^{12} \mathrm{PCI}$ BT and AASHTO II type, which are PSC girders developed by New England Highway Department, Prestressed Concrete Institute, and AASHTO, respectively. ${ }^{1,9,13-15}$

\section{Openings in a structural member}

Completely new design concept introduced in the current study is making openings in the I-type girder web. Several advantages are attained by introducing holes in the web. First of all, it is recognizable by intuition that self-weight of the girder, and design load, is reduced. The volume or weight reduction of a girder after the introduction of holes was about $8 \%$ for the test girder, which will be shown in the following section. The amount is about $4 \%$ when the volume of deck slab is taken into consideration. But it should be pointed out that these numbers should be larger since the end blocks, which have been usually installed, were removed. Secondly, the negative moment introduced at girder ends is unnecessary for simple span design, and large number of anchorages introduce high compressive stresses in end zone. To mitigate this high compressive stress typically thick end blocks are installed. Some of the anchorage devices are moved into the holes, and correspondingly, they are removed from the girder ends. This reduces the magnitude of compressive stress developed at end zones. Thirdly, ideally speaking, the negative moments introduced by prestressing should follow the shape of moment diagram generated by total applied loads as much as possible. The efficiency of prestressing concept will be maximized when prestressing steels are installed only where negative moments are required, and the amount of prestressing steels can be reduced. This can be achieved more efficiently with
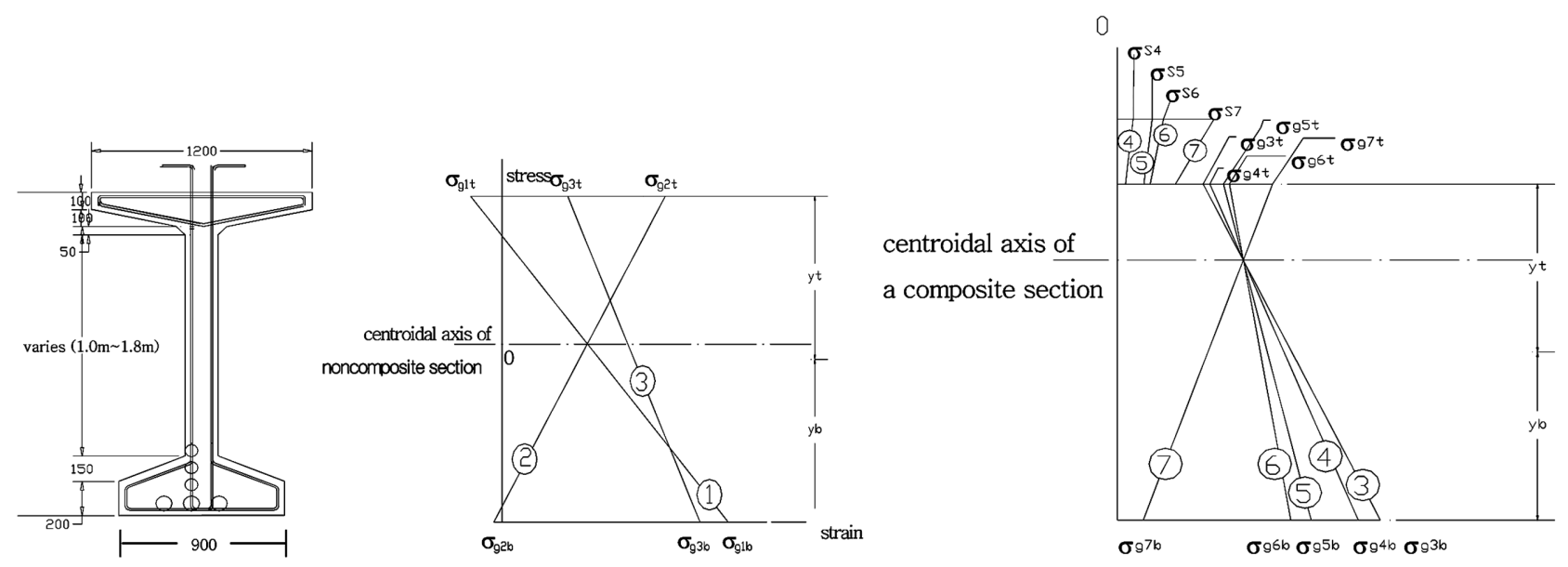

Fig. 1 Stress changes at different loading stages. ${ }^{9}$ 
HWPC girders since anchorage devices are not necessarily to be placed at girder ends and can be anchored at any openings.

These two design concepts, i.e. the web openings and the incremental prestressing method, are combined together to form a whole new concept for HWPC (Holed Web Prestressed Concrete) girder design. Research about transverse openings in structural members have not been conducted except relatively small size holes for utility duct and pipes in building structural members. ${ }^{16}$

The flexural stiffness of the girder is not much affected by the introduction of openings. It is because the upper and lower flanges of the girder provide most of the area in the cross-section. Also the center of the holes are pretty close to the neutral axis of the girder cross-section, and the thickness of the web is pretty shallow two. Moment of inertia of the girder cross-section at the very center too of the hole according to the sectional centroid is about $94 \%$ of the moment of inertia for solid section. This value increases to about 98\% after the deck slab is hardened considering the composite action. There are some other benefits. Lateral wind load, even though it was not considered in this study, also should be diminished considerably. Girders do not block the view of the other side, and openings also provide aesthetic attraction. Another advantage of HWPC will be the ease in the construction of continuous bridges. Because of the exposed anchoring system, insertion of continuous prestressing steels and additional prestressing for a specific strand will be easy. Multi-span continuous girder bridges become much more economical comparing with conventional continuous PSC girder bridges.

A typical appearance of HWPC girders is given in Fig. 2. Circular openings are inserted in the web equidistantly. Half of the total anchorages was placed inside the holes, and the other half was left at girder ends.

\section{Experiment for a full scale HWPC girder}

In order to verify the performance of the newly proposed holed web prestressed concrete girder, a full size girder was designed, fabricated, and a flexural test was conducted.

\subsection{Girder design}

A HWPC girder with the length of $50 \mathrm{~m}$ and the height of $2 \mathrm{~m}$ was designed based on strength design method and allowable stresses were checked at necessary loading stages. In domestic industry, PSC girders have been applied for the span length of shorter than about $45 \mathrm{~m}$. Therefore, $50 \mathrm{~m}$ span length can be a huge breakthrough in embodiment of the new design concept. There are 18 openings equally spaced in the web (Fig. 2). There is no opening at close to girder ends where prestressing steels are closely spaced and stress concentration in concrete is high. The diameter of each opening is $1 \mathrm{~m}$, and center to center distance of two adjacent openings is $2.5 \mathrm{~m}$. There are 12 anchorage devices on each side; 6 of them are anchored at girder ends, and the other 6 are anchored inside of each opening (Fig. 2). Since the girder span was more than $44 \mathrm{~m}$, the live load moment was dominated by the design lane load of DL-24. ${ }^{17}$ Minimum thickness for the deck slab is given as not less than $220 \mathrm{~mm}$ or $4 \mathrm{~L}+130 \mathrm{~mm}$ in design specification, where $\mathrm{L}$ is the clearance between two adjacent parallel girders. Since current study is for a single girder, $240 \mathrm{~mm}$ was selected to satisfy the first criterion only.

For the design of shear, two different approaches can be considered. One is the traditional sectional design method which is based on Bernoulli's hypothesis. It computes factored shear load at each location through the girder length. The other one is the strut-tie model based on plasticity theory. For the holed web PSC girders, since most of the regions belong to disturbed region due to closely spaced web openings, it is appropriate to check all reinforcing bars using strut-tie analysis. For the current form of HWPC, the amount of shear reinforcement was first calculated using sectional analysis, and it was checked again with strut-tie model. The total nominal shear strength was found by summing the contributions of the steel and the concrete, and the vertical reinforcing steels supposed to be put on the openings were added to the reinforcement locating between two adjacent openings. It turned out that the reinforcement satisfies the requirement based on strut-tie calculation, and Fig. 3 represents the strut-tie model analyzed. Linear finite element analysis was also performed in order to find local

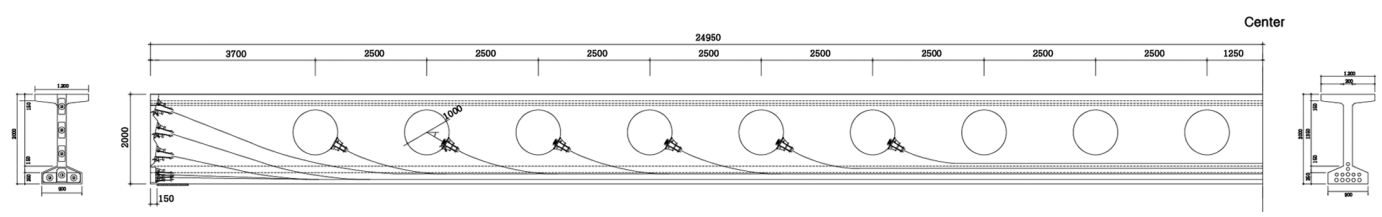

Fig. 2 HWPC girder configuration (left half of a girder).

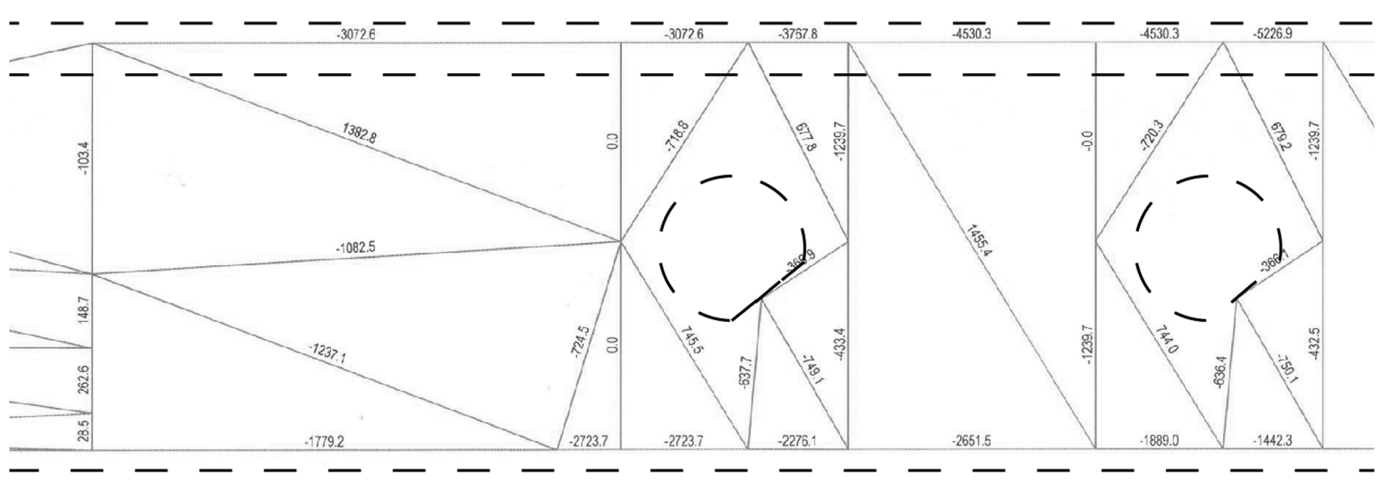

Fig. 3 Strut tie model (unit: $k N$ ). 


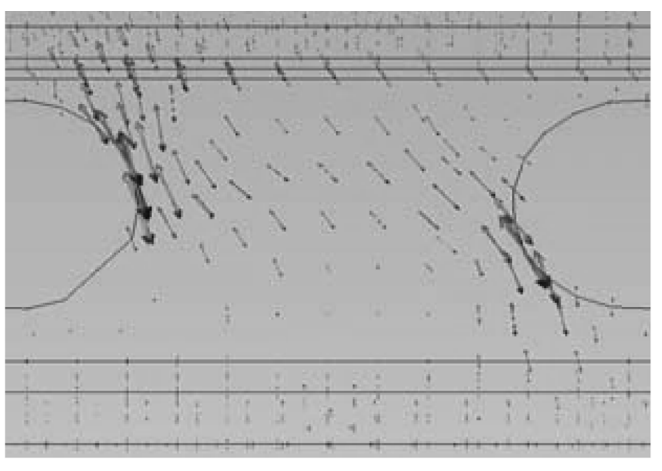

(a) Maximum principal stress

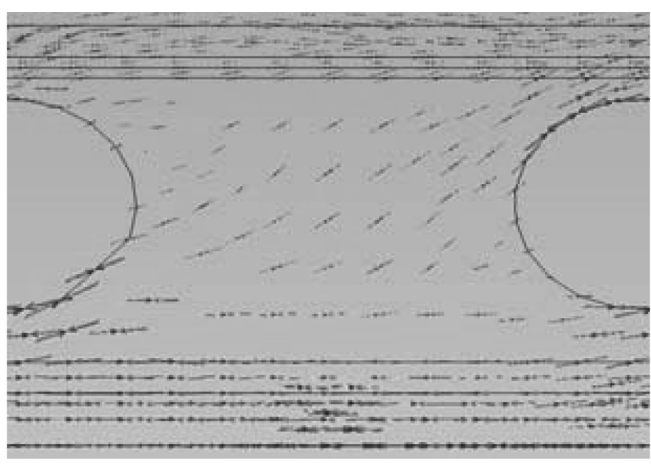

(b) Minimum principal stress

Fig. 4 Principal stresses near holes.

stresses near holes (Fig. 4), and additional diagonal reinforcement was placed based on maximum principal stress direction.

Dimensions of the designed HWPC girder are given in Table 1, and design conditions and material properties are tabulated in Table 2. Design loads are given in Table 3, and the estimate of loss of prestress force based on the consideration of separate contributions to total loss is given in Table 4.

Required prestressing force was calculated based on permissible stresses developed in the member at various loading stages, and corresponding prestressing force was $1,784 \mathrm{kN}$ for each of 6 anchorages located at both ends, which was corresponding to the first stage prestressing. For the second stage prestressing, $1,249 \mathrm{kN}$ was used for each of 6 anchorages located inside holes. The negative moment introduced through prestressing is compared with the external moment due to design loads in Fig. 5. In the figure, PS1 and PS2 correspond to the first and the second stage of prestressing, respectively. DL and LL are dead load and live load. DL_G
Table 3 Loads for design.

\begin{tabular}{c|c}
\hline Loads & Magnitude for design \\
\hline \hline Weight of the girder $(\mathrm{kN} / \mathrm{m})$ & 14.9 \\
\hline Weight of the girder and slab $(\mathrm{kN} / \mathrm{m})$ & 29.6 \\
\hline Dead load from pavement $(\mathrm{kN} / \mathrm{m})$ & 2.7 \\
\hline Impact factor for live load moment & 0.167 \\
\hline Design live load $(\mathrm{kN})$ & 378 \\
\hline Live load moment $(\mathrm{kN} \cdot \mathrm{m})$ & 5,030 \\
\hline
\end{tabular}

and DL S designate the self-weight of the girder and slab. DL2 is the external dead load such as asphalt and guard fence, and M_cr is the cracking load. It can be seen from the figure that anchorages for those holes near center of the girder are not required. This kind of distributed anchorage configuration reduces the amount of principal compressive and tensile stresses developed in end zones, and consequently, the thickness of girder ends can be reduced to the

Table 1 Dimensions of the test girder.

\begin{tabular}{c|c|c|c|c|c|c}
\hline Support type & Girder length & Girder height & Deck slab width & Deck slab thickness & Hole diameter & Hole location from the bottom \\
\hline \hline Simple & $50 \mathrm{~m}$ & $2,000 \mathrm{~mm}$ & $2,400 \mathrm{~mm}$ & $240 \mathrm{~mm}$ & $1 \mathrm{~m}$ & $1.15 \mathrm{~m}$ \\
\hline
\end{tabular}

Table 2 Design conditions and material properties for the HWPC girder.

\begin{tabular}{|c|c|c|c|}
\hline \multirow{2}{*}{\multicolumn{2}{|c|}{ 28-day strength of concrete for girder (MPa) }} & Target & 55 \\
\hline & & Test (average of 3 cylinders) & 52.1 \\
\hline \multirow{2}{*}{\multicolumn{2}{|c|}{ 28-day strength of concrete for deck slab (MPa) }} & Target & 27 \\
\hline & & Test (average of 3 cylinders) & 28.2 \\
\hline \multicolumn{3}{|c|}{ Strength of concrete at time of initial prestressing (MPa) } & 44 \\
\hline \multirow{2}{*}{\multicolumn{2}{|c|}{ Elastic modulus (GPa) }} & Girder & 32 \\
\hline & & Deck slab & 25 \\
\hline \multicolumn{3}{|c|}{ Live load } & DL-24 \\
\hline \multirow{4}{*}{ Allowable stresses for concrete } & \multirow{2}{*}{ Initial loading stage } & Compression & 0.55 \\
\hline & & Tension & 0.50 \\
\hline & \multirow{2}{*}{ Service loading stage } & Compression & 0.40 \\
\hline & & Tension & 0.50 \\
\hline \multirow{4}{*}{ Prestressing strands } & Nominal area $\left(\mathrm{mm}^{2}\right)$ & \multicolumn{2}{|c|}{138.7} \\
\hline & Ultimate strength (MPa) & \multicolumn{2}{|c|}{1,900} \\
\hline & Yield strength (MPa) & \multicolumn{2}{|c|}{1,600} \\
\hline & Elastic modulus (GPa) & \multicolumn{2}{|c|}{200} \\
\hline \multirow{2}{*}{ Reinforcing steel } & Nominal diameter (mm) & \multicolumn{2}{|c|}{$12.7,19.1$} \\
\hline & Yield strength (MPa) & \multicolumn{2}{|c|}{400} \\
\hline
\end{tabular}


Table 4 Immediate and time-dependent loss in prestressing.

\begin{tabular}{c|c|c}
\hline \multicolumn{3}{c}{ Loss at the center of the girder (MPa) } \\
\hline \hline \multirow{3}{*}{ Immediate losses } & Friction & 167 \\
\cline { 2 - 3 } & Anchorage slip & 0 \\
\cline { 2 - 3 } & Elastic shortening & 51 \\
\hline \multirow{4}{*}{ Time-dependent losses } & Drying shrinkage & 36 \\
\cline { 2 - 3 } & Creep & 144 \\
\cline { 2 - 3 } & Relaxation & 8.5 \\
\hline
\end{tabular}

* Effective ratio $=0.821$

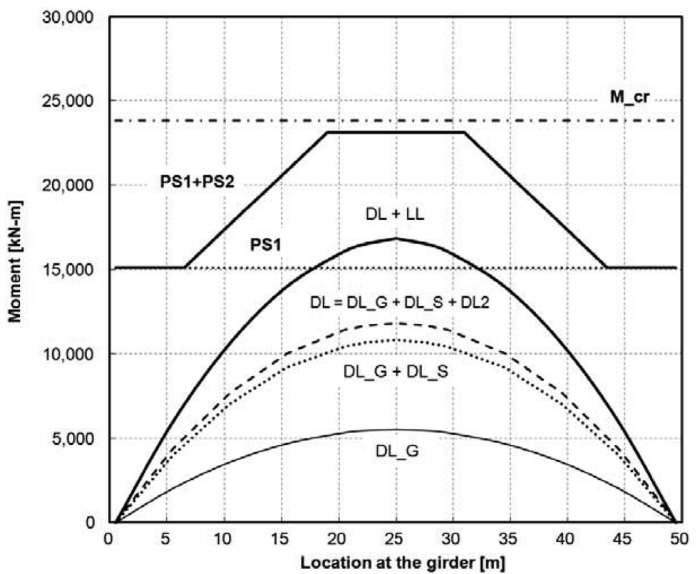

Fig. 5 Comparison of moments introduced by external loads and prestressing force.

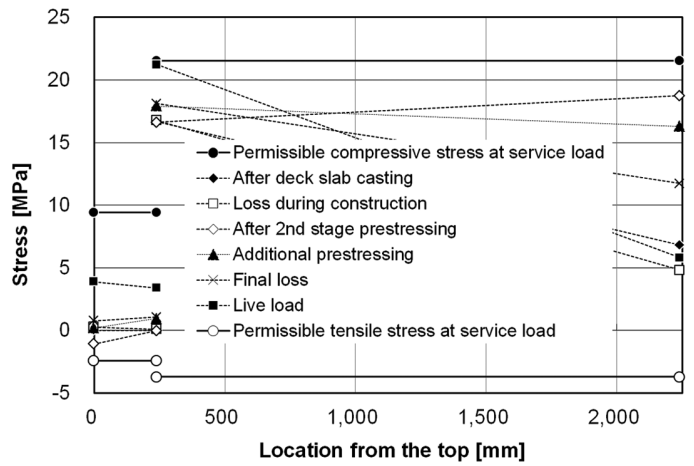

Fig. 6 Stress change according to the construction sequence.

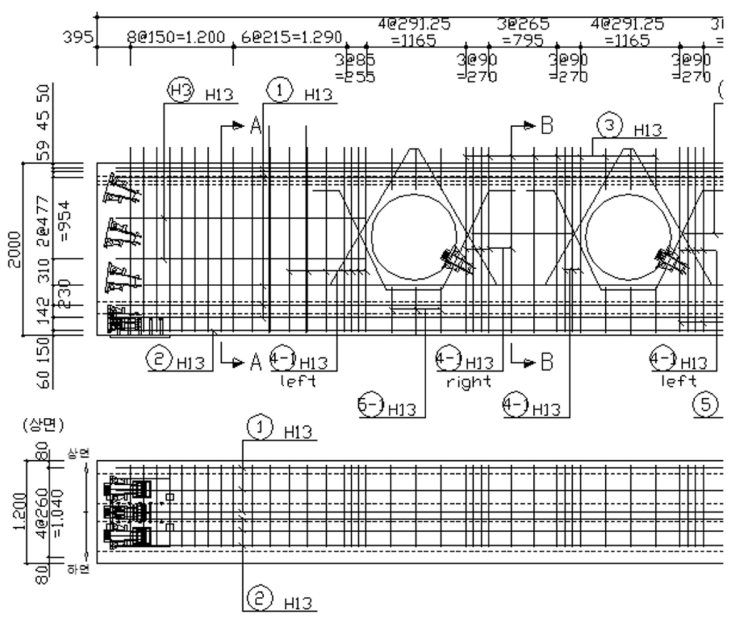

(a) Left end

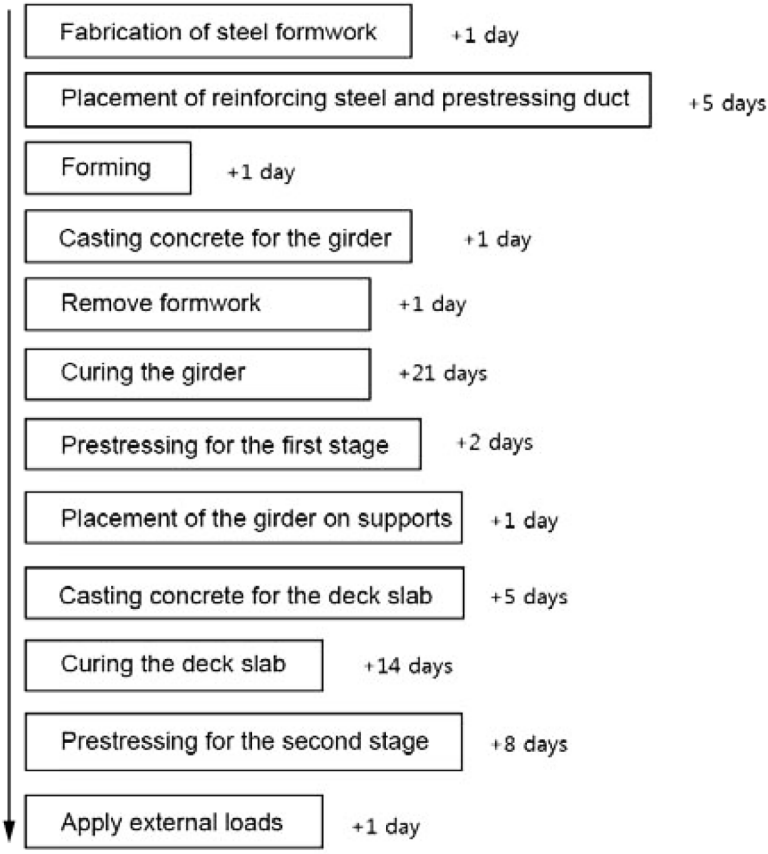

Fig. 7 Experimental procedure.

same thickness of girder web. The overall shape of the negative moment envelope covers all the positive moment developed in the girder, and it tells the efficiency of distributed prestressing method utilizing web openings.

Stress profile changes as construction proceeds and prestressing forces are introduced accordingly. Figure 6 shows the stress development at various locations in the girder according to construction sequence, and it can be seen that all stresses fall between the allowable compressive and tensile stress ranges.

\subsection{Girder fabrication}

The whole process from the fabrication of the girder to the flexural test is shown in Fig. 7 as a diagram. Reinforcing details of the girder are given in Figs. 8, 9, and the thickness of concrete cover was $50 \mathrm{~mm}$.

The usage of self-consolidating concrete (SCC) in the construction of bridge members has been limited so far. SCC was used for

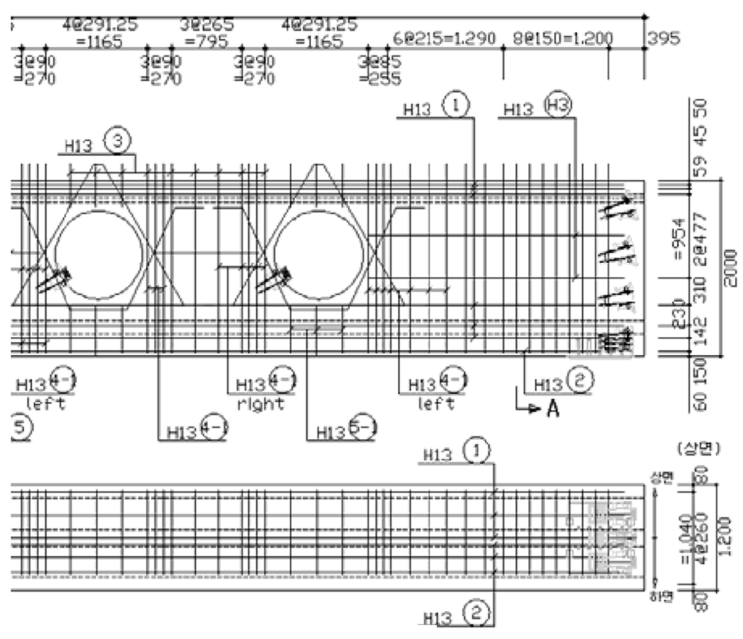

(b) Right end

Fig. 8 Reinforcing details of the girder. 


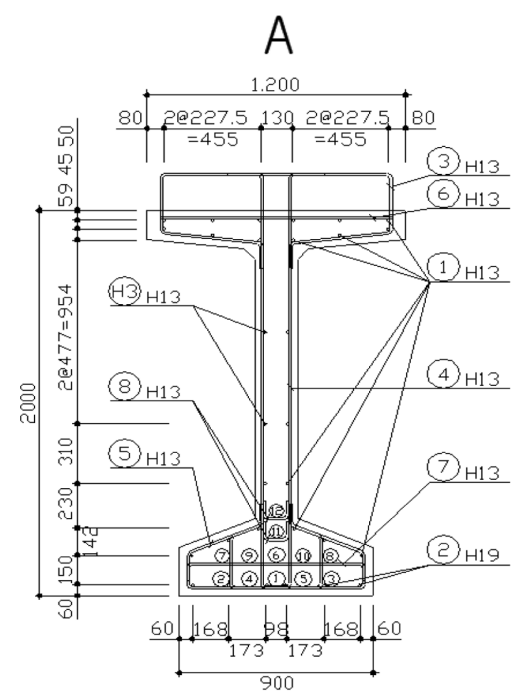

(a) Girder and reinforcement

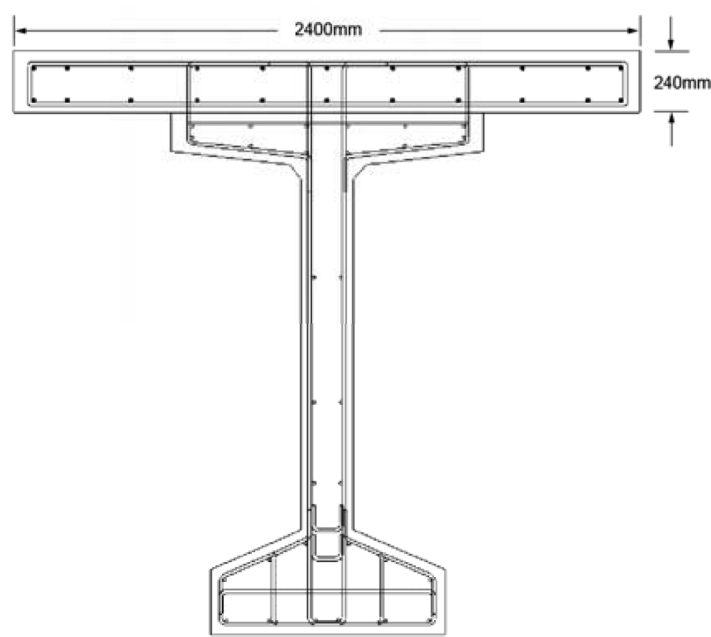

(b) After casting of deck slab

Fig. 9 Reinforcing details at $A$ in Fig. 8.

the fabrication of the girder in this research. It is highly flowable concrete that can fill the formwork, and encapsulate the reinforcement without any mechanical consolidation. It accelerates construction through higher rate of casting and reduces cost for girders. Properly designed SCC is expected to provide similar properties as the conventional counterparts except for the high workability. Mix proportions of the girder and deck slab concrete are given in Table 5, and slumps are given in Table 6.

Curing in live steam at atmospheric pressure dramatically increases the rate of strength development of concrete at the early age. It also cuts down the amount of drying shrinkage and creep strains by one third. ${ }^{18}$ In addition, steam curing allows increased production by a more rapid turnover of formwork, shorter curing periods before prestressing, and less damage to the structural members during handling. Steam curing is used primarily for precast concrete products, but can also be used for enclosed cast-in-place structures like current case. Concrete was allowed to remain at room temperature for 3 hours after casting before being exposed to steam, to allow the girder to undergo some initial hydration and improve its stability. This will improve later strength. The rate of temperature rise was $20^{\circ} \mathrm{C} / \mathrm{h}$, and the soaking time was about 4 hours at $65^{\circ} \mathrm{C}$. The rate of cooling was about $15^{\circ} \mathrm{C} / \mathrm{h}$, and, after then, the temperature was kept at $15 \sim 20^{\circ} \mathrm{C}$ for certain period of time. Photos taken at various experimental stages are given in Fig. 10.

\subsection{Loading test procedure}

A flexural test using two loading points was conducted (Fig. 11). Loads were applied using two actuators that were placed at the center and $5 \mathrm{~m}$ apart each other. Each of the actuators had the maximum load capacity of $2,000 \mathrm{kN}$, and maximum stroke of $930 \mathrm{~mm}$.

A large number of gages were placed at various locations of the girder to acquire data such as displacements, strains, and forces. Strain gages were attached for the reinforcing steels at horizontal and vertical directions (Figs. 12 and 13). LVDTs were installed to measure displacements at the center of the girder, the quarter points of the girder, and the supports.

Cracks formed at certain load levels starting from shear cracks and developed to flexural cracks. Girder surface was painted with white color in order to make it easy to observe cracks with naked eyes. And grid lines were made to located crack path. Application of loading was stopped periodically and crack lines were marked on the surface (Fig. 14).

Load was applied only until well distributed shear cracks were formed in the web. It was partly because similar experiment with a full size holed web PSC girder has not been conducted so far, and safety was the first concern during the experiment. Consequently, load was not applied up to the full load capacity of the girder.

\section{Experimental results}

The load-deflection behavior of the girder is given in Fig. 15,

Table 5 Mix proportion of concrete.

\begin{tabular}{c|c|c|c|c|c|c|c|c|c}
\hline & w/c (\%) & s/a (\%) & $\begin{array}{c}\text { Water } \\
\left(\mathrm{kN} / \mathrm{m}^{3}\right)\end{array}$ & $\begin{array}{c}\text { Cement } \\
\left(\mathrm{kN} / \mathrm{m}^{3}\right)\end{array}$ & $\begin{array}{c}\text { Fly ash } \\
\left(\mathrm{kN} / \mathrm{m}^{3}\right)\end{array}$ & $\begin{array}{c}\text { Silica fume } \\
\left(\mathrm{kN} / \mathrm{m}^{3}\right)\end{array}$ & $\begin{array}{c}\text { Sand } \\
\left(\mathrm{kN} / \mathrm{m}^{3}\right)\end{array}$ & $\begin{array}{c}\text { Gravel } \\
\left(\mathrm{kN} / \mathrm{m}^{3}\right)\end{array}$ & $\begin{array}{c}\text { s.p.* } \\
\left(\mathrm{kN} / \mathrm{m}^{3}\right)\end{array}$ \\
\hline \hline Girder & 24.8 & 50.3 & 1.75 & 4.96 & 1.41 & 0.71 & 6.88 & 6.87 & 0.09 \\
\hline Deck slab & 39.3 & 47.1 & 1.65 & 3.76 & 0.42 & - & 2.38 & 8.95 & 0.002 \\
\hline
\end{tabular}

*high range water reducing admixture, carboxylated acrylic ester copolymers (polycarboxylates).

Table 6 Slump flow and air content.

\begin{tabular}{|c|c|c|c|c|c|c|c|}
\hline \multicolumn{6}{|c|}{ Girder } & \multicolumn{2}{|c|}{ Deck slab } \\
\hline \multicolumn{3}{|c|}{ Slump flow (mm) } & \multicolumn{3}{|c|}{ Air content (\%) } & \multirow{2}{*}{$\begin{array}{l}\text { Slump flow } \\
(\mathrm{mm})\end{array}$} & \multirow{2}{*}{$\begin{array}{c}\text { Air conten } \\
(\%)\end{array}$} \\
\hline $0 \mathrm{~min}$. & $30 \mathrm{~min}$. & $60 \mathrm{~min}$. & $0 \mathrm{~min}$. & $30 \mathrm{~min}$. & $60 \mathrm{~min}$. & & \\
\hline 630 & 620 & 610 & 4.4 & 4.0 & 3.8 & 155 & 4.2 \\
\hline
\end{tabular}




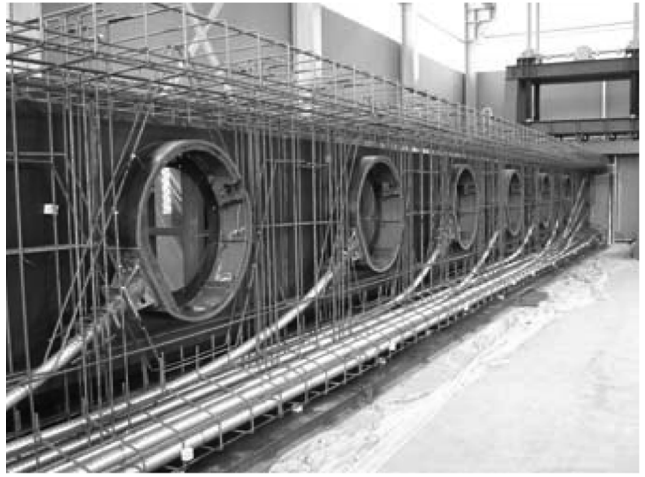

(a) Reinforcing bars and ducts

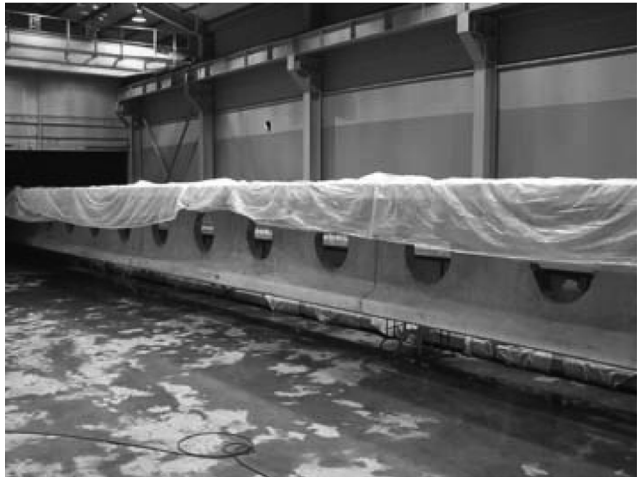

(c) Curing after first stage of prestressing

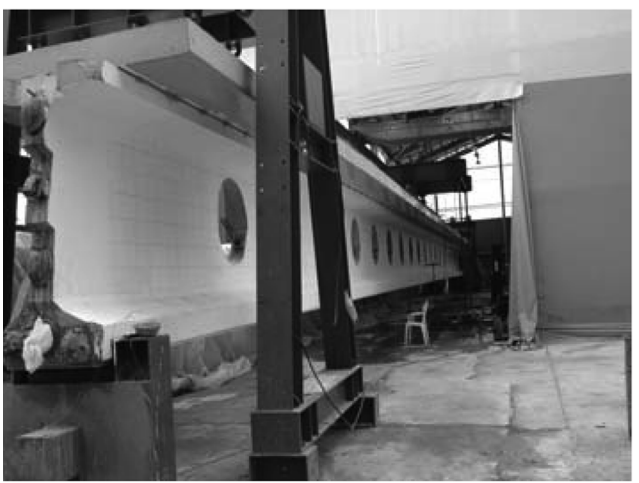

(e) After second stage prestressing

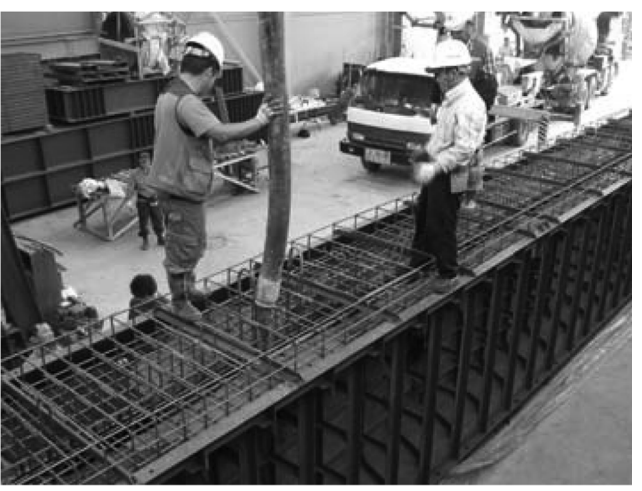

(b) Pouring of girder concrete

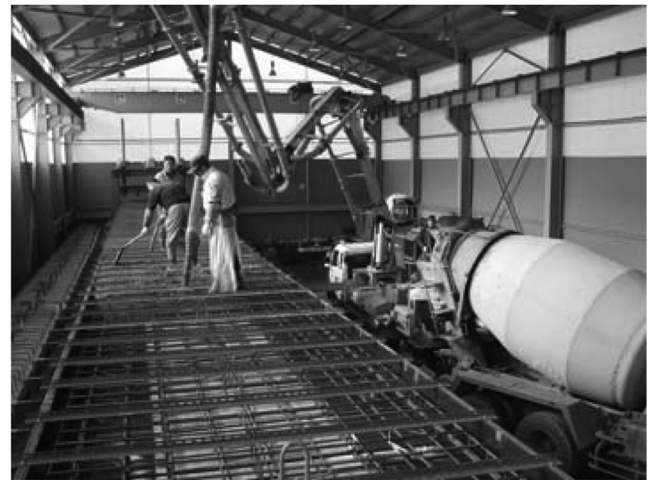

(d) Casting deck slab

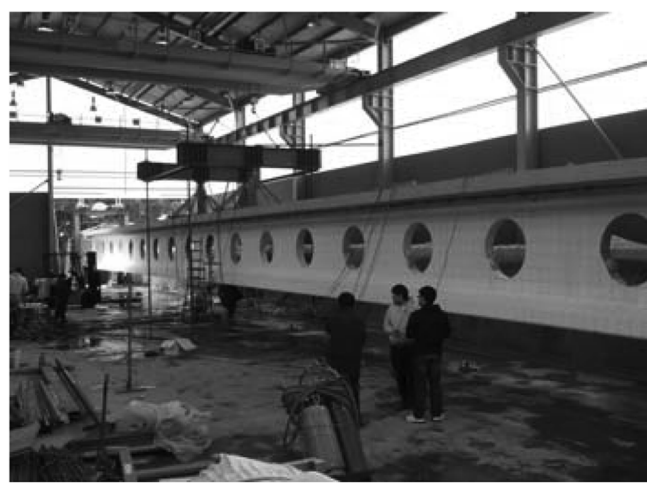

(f) Preparation of test

Fig. 10 Manufacturing and testing of the girder.

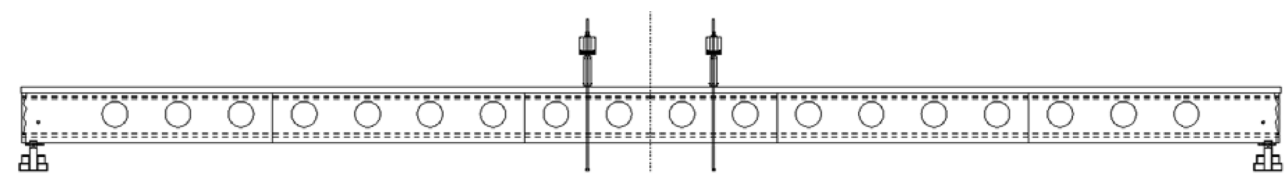

Fig. 11 Loading frame configuration.

(L2)

Fig. 12 Gage locations of the girder. 


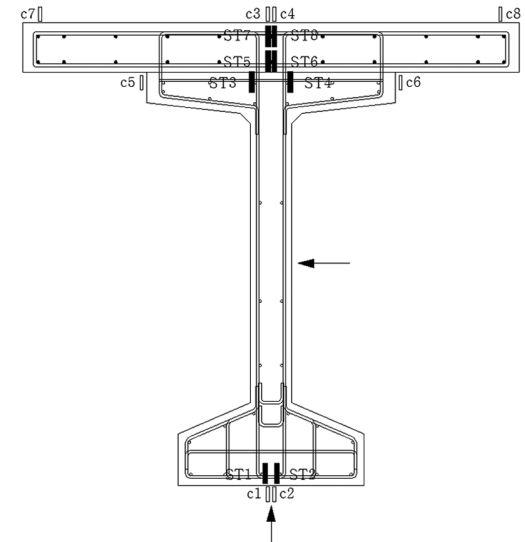

(a) at 1

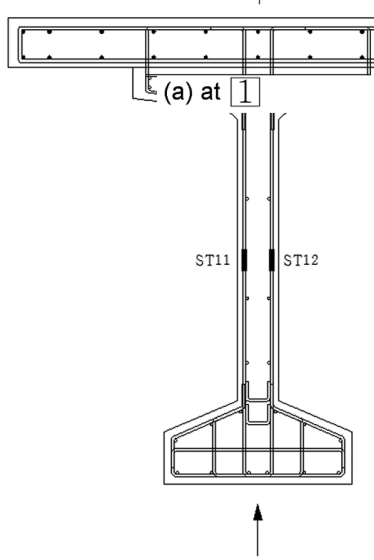

(c) Right side of 2

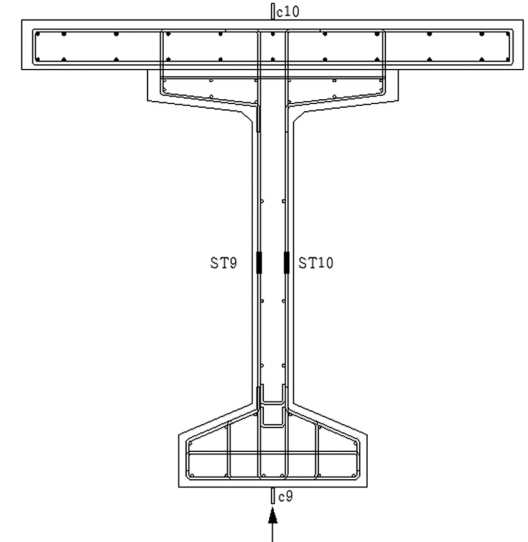

(b) Left side of 2

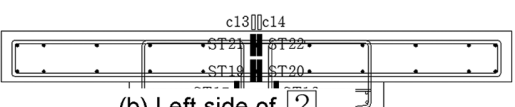

(b) Left side of 2

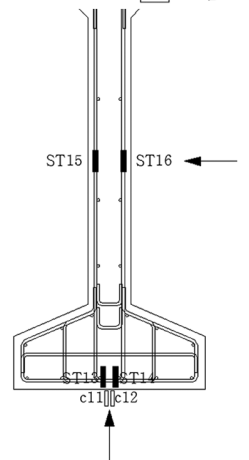

(d) at 3

Fig. 13 Gage locations in transverse direction in Fig. 12.

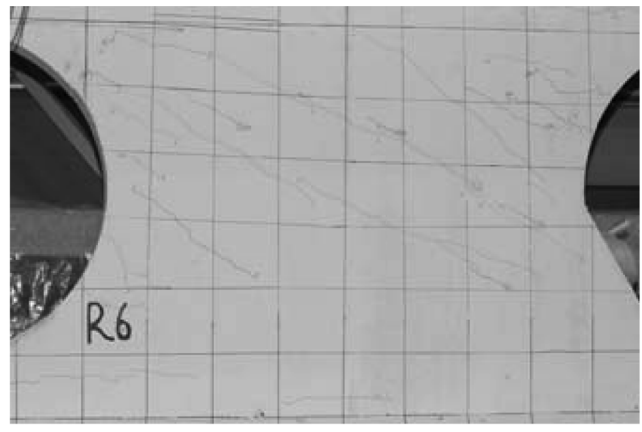

(a) Diagonal cracks (between R6 and R7)

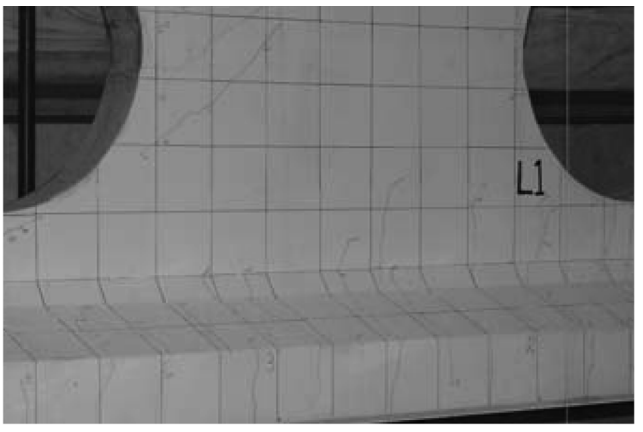

(b) Flexural cracks (between L1 and L2)

Fig. 14 Crack formation.

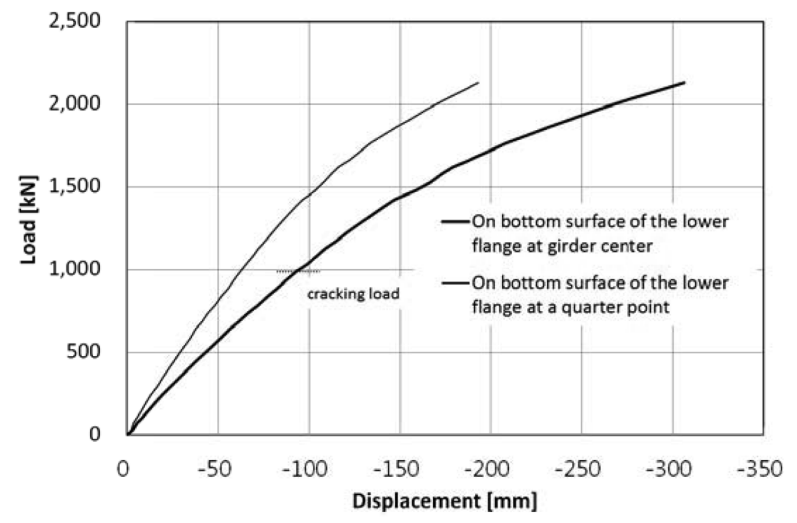

Fig. 15 Load-deflection relation of the girder. and other deflection values at some calculated loads are given in Table 7. The magnitude of loads in the figure was sum of two values obtained from both actuators.

The deflection at the cracking load of $992 \mathrm{kN}$ for flexural cracks was $92.7 \mathrm{~mm}$, which was slightly larger than the estimated theoretical value of $83.6 \mathrm{~mm}$. And, the deflection at girder center occurred under the calculated live load was $32.8 \mathrm{~mm}$, and it was pretty close to the theoretical value of $31.9 \mathrm{~mm}$. For bridges, KHBDS (the Korea Highway Bridge Design Specification) requires that for simple or continuous spans, the deflection due to live load plus impact should not exceed 1/800 of the span, which is $62.5 \mathrm{~mm}$ for the current test girder, except on bridges in urban areas used in part by pedestrians, on which the ratio preferably shall be $1 / 1000$. The measured deflection under design live load of 
Table 7 Comparison of design value and test results.

\begin{tabular}{c|c|c|c}
\hline Load type & Loads $(\mathrm{kN})$ & Calulated deflections at girder center $(\mathrm{mm})$ & Measured deflections at girder center $(\mathrm{mm})$ \\
\hline \hline Live load & 378 & 31.9 & 32.8 \\
\hline Cracking load & 992 & 83.6 & 92.7 \\
\hline Load at yielding & 3,171 & 267.4 & - \\
\hline Failure load & 4,094 & 345.3 & - \\
\hline
\end{tabular}

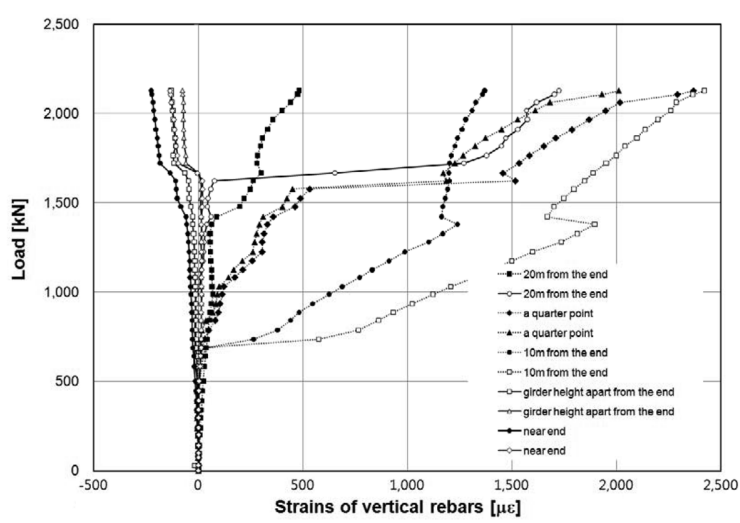

Fig. 16 Change of longitudinal steel strains at the middle of the girder.

$375 \mathrm{kN}$ in the current experiment well satisfied the specified criterion.

Figure 16 reveals the longitudinal strain distribution through the depth at the middle of the girder according to the increment of loads. Tensile strain is given as positive, and compressive strain is negative. The neutral axis moved up when the load reached at about $1,722 \sim 1,765 \mathrm{kN}$. It implies that the flexural cracks, which were serious enough to change the location of neutral axis, were formed at the center at this load level. This can be confirmed from the longitudinal steel strains, where steep increase of strains were observed at the same load level.

When shear cracks form, the strains in the vertical reinforcement increase in a large amount. Several locations were chosen for the measurement of vertical steel strains at the middle height of the web. Selected locations were girder ends, literally critical section ( $2 \mathrm{~m}$ away from the end), $10 \mathrm{~m}$ from the end, the quarter point ( $12.5 \mathrm{~m}$ away from the end), and $20 \mathrm{~m}$ from the end. Large increase in the strain started at gages located $10 \mathrm{~m}$ away from the end at the load of $688 \mathrm{kN}$ (Fig. 18). Strains for the quarter point gages started to increase gradually right after that, and big jump was observed at $1,577 \mathrm{kN}$. From this observation, it can be told that shear cracks formed near $10 \mathrm{~m}$ location first, and propagated gradually to the center of the girder. This phenomenon is natural since shear stresses at the end side are larger and monotonically decreasing to the loading point. By naked eyes, on the other hand, shear cracks were observed in the web between two adjacent holes only when the load reached at about $1,200 \mathrm{kN}$, and turned out naked eyes do not detect microcracks developed at the early stage. Vertical steel strains near girder ends did not show tensile stress and indeed revealed small compressive stresses since they are close to the support and end anchoring devices.

Relatively large compressive stresses develope near anchorage devices located in the hole. Gage r1 r6 are reinforcing steel strains around holes. Gage r1 and r5, which show large deformation after certain load level (Fig. 19), are those two gages near anchorage

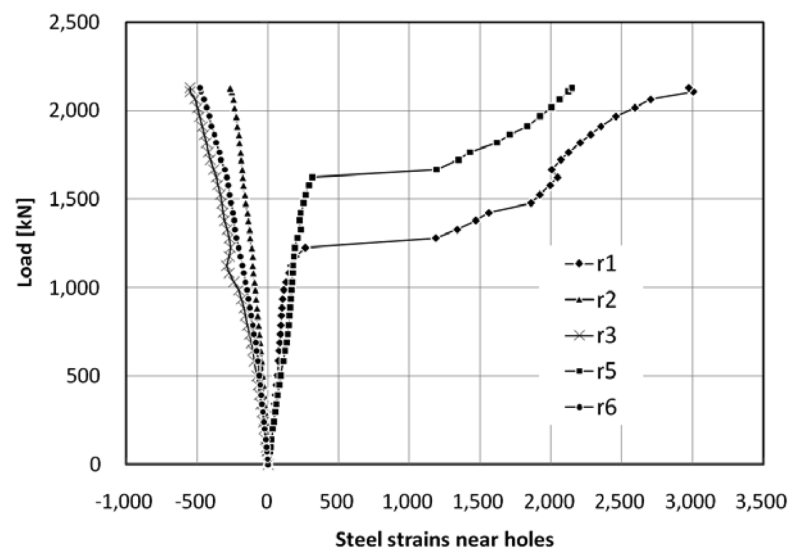

Fig. 17 Longitudinal steel strains at the center and at a quarter point of the girder.

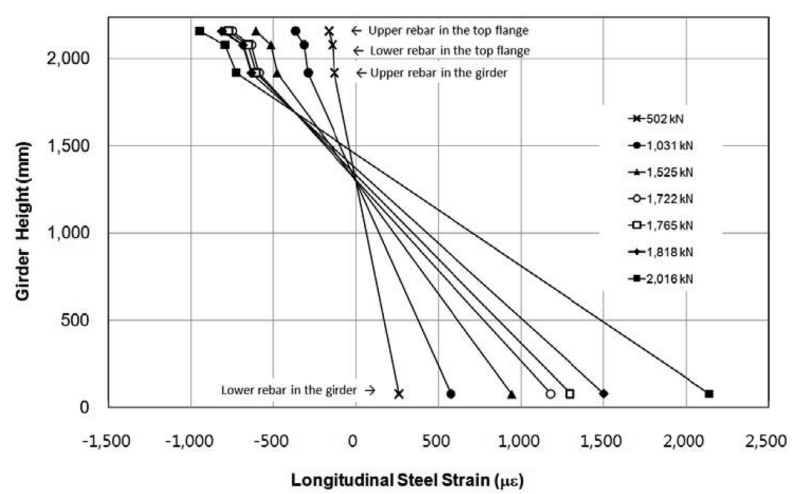

Fig. 18 Strains of vertical reinforcing bars.

devices. Since reinforcing steels where gages are attached lay almost perpendicular to the prestressing steel direction, they carry large tensile stresses.

Gages on the concrete surface show pretty much monotonic behavior up to about $1,500 \mathrm{kN}$ (Fig. 20). After 1,722 kN, strains on the bottom surface of lower flange at the center of the girder decrease. This should not be interpreted as decrease in strains, instead, it is kind of malfunctioning in gages after flexural cracks formed on the bottom. It can be explained from (Fig. 16), where it is recognized that neutral axis moves up at this load level.

Crack maps on the girder web were obtained at several discrete loading steps (Fig. 21). When load was applied up to certain level, shear cracks started to develop in the web, and as the load further increases numerous diagonal shear cracks are formed as shown in the figure. These shear cracks have been developed continuously and might have resulted in abrupt shear failure. At 1,568 kN, flexural cracks at bottom flange were observed by naked eyes, but this was not enough to change the location of neutral axis at center (see Fig. 16). From $1,764 \mathrm{kN}$ the crack formation influenced on the stiffness of the girder center. To avoid brittle shear failure and 


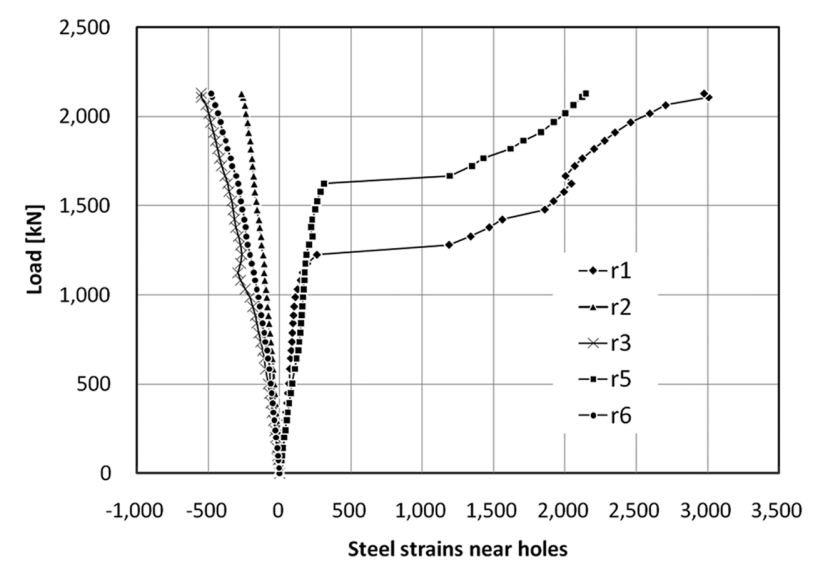

Fig. 19 Strains of reinforcing steels around holes.

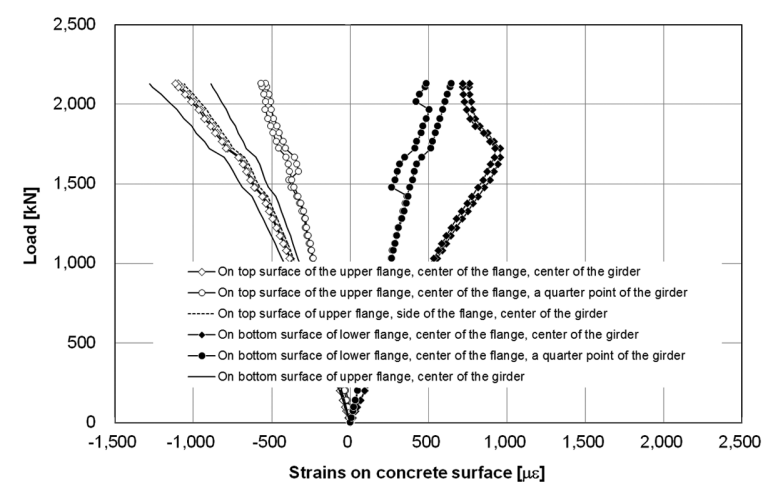

Fig. 20 Strain gages attached on the surface of concrete at various locations.

guarantee ductile flexural failure, reinforcing details between adjacent openings should be enhanced in order to ensure flexural failure.

\section{Conclusions}

The holed web prestressed concrete (HWPC) girder is a new design concept that has many advantages against a conventional I- type concrete girder design. By the introduction of openings in the web, it is possible to extend span length longer than $50 \mathrm{~m}$ with limiting the girder height at around $2 \mathrm{~m}$. Several conclusions are made from up to date design concept and experimental results.

1) A girder design method which combines the holed web structure and the incremental prestressing turned out to be a rational method for PSC girder design enabling to achieve a span length of more than $50 \mathrm{~m}$ with the girder height of $2 \mathrm{~m}$.

2) Incremental prestressing concept introduces only certain level of stresses in a member at each loading stage, and longer span length can be achieved with the same girder depth when only required amount of presstress force is applied between two loading stages.

3) Openings made in the web not only reduce the self-weight of the girder but also make it possible to distribute anchorage devices. Since the number of anchorages at girder ends is reduced, compressive and bursting stresses at girder ends reduced.

4) It was possible to remove thick end block of the girder since the number of anchorage devices at ends was reduced by half comparing with typical I-type girders.

5) The initial flexural cracks found on the bottom surface of the girder do not change the neutral axis right away and, instead, about $200 \mathrm{kN}$ additional load was required until to see the change in the location of neutral axis.

6) Large increase of the strain in the vertical reinforcing steels was detected at the load less than $700 \mathrm{kN}$, and then shear cracks propagated to the girder center gradually. However, naked eyes detected diagonal shear cracks only when the load reached at $1,200 \mathrm{kN}$.

7) Strains in vertical reinforcing steels near girder ends did not show tensile strains and revealled small compressive strains instead. It implies that area near girder ends cannot be designed using the sectional design method and strut-tie analysis will be a possible alternative.

8) A HWPC girder satisfies allowable stresses at various loading stages, and the designed test girder satisfied deflection limit and cracking load specified in the KHBDS. The deflection occurred under the DL-24 design live load was $33 \mathrm{~mm}$, and it

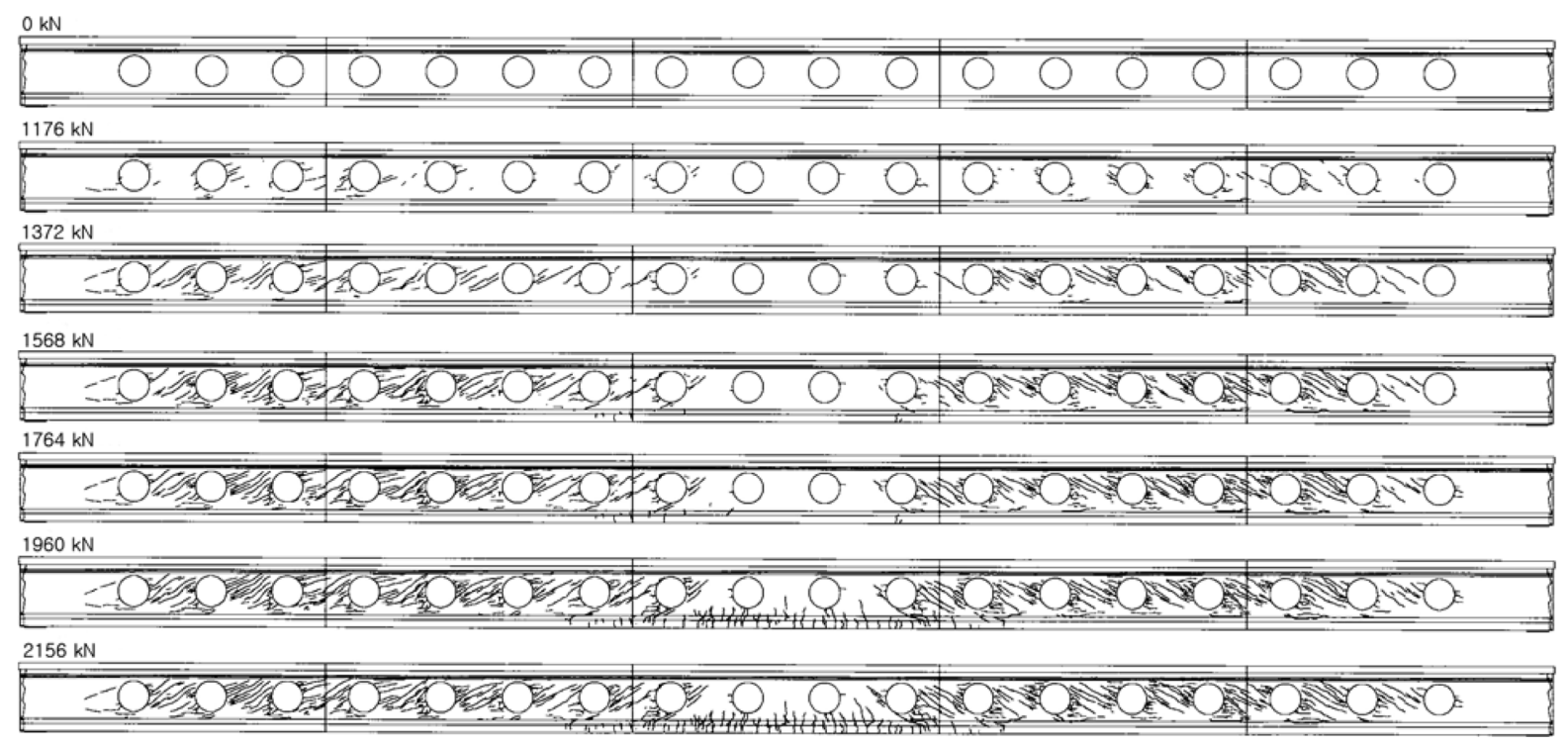

Fig. 21 Crack patterns observed on girder web. 
satisfied the required deflection limit of $1 / 800$ of the span, which is $62.8 \mathrm{~mm}$, specified in the KHBDS. Further researches will be required in order to apply the HWPC design concept for bridges.

\section{Acknowledgments}

This research was supported by a grant from Construction Technology Innovation Program (CTIP, 05' D02-01) funded by Ministry of Land, Transportation and Maritime Affairs (MLTM) of Korean government.

\section{References}

1. Bardow, A. K., Seraderian, R. L., and Culmo, M. P., "Design, Fabrication and Construction of the New England Bulb-Tee Girder," PCI Journal, Vol. 42, No. 6, 1997, pp. 30 40.

2. Castrodale, R. W. and White, C. D., NCHRP Report 517: Extending Span Ranges of Precast Prestressed Concrete Girders, Research Sponsored by the American Association of State Highway and Transportation Officials in Cooperation with the Federal Highway Administration, Transportation Research Board, Washington, D.C., 2004.

3. Fitzgerald, J. B. and Stelmack, T. W., "Spliced Bulb-Tee Girders Bring Strength and Grace To Pueblo's Main Street Viaduct," PCI Journal, Vol. 41, No. 6, 1996, pp. 40 54.

4. Garcia, A. M., "Florida's Long Span Bridges: New Forms, New Horizons," PCI Journal, Vol. 38, No. 4, 1993, pp. 34 49.

5. Janssen, H. H. and Spaans, L., "Record Span Spliced BulbTee Girders Used in Highland View Bridge," PCI Journal, Vol. 39, No. 1, 1994, pp. 12 19.

6. PCI, New England Bulb Tee Post-Tensioned Design Guidelines, Report No. PCINER-01-PTDG, PCI, 2001.
7. Rabbat, B. G. and Russell, H. G., "Optimized Sections for Precast Prestressed Bridge Girders," PCI Journal, Vol. 27, No. 4, 1982, pp. 88 104.

8. Han, M. Y. and Hwang, E. S., "Development of Longer and Economical Incrementally Prestressed Concrete (IPC) Girder," The 1st fib Congress, Osaka, Japan, 2002, pp. 87 88.

9. Han, M. Y., Hwang, E. S., and Lee, C., "Prestressed Concrete Girder with Multistage Prestressing Concept," ACI Structural Journal, Vol. 100, No. 6, 2003, 731 pp.

10. Gergeley, P. and Sozen, M. A., "Design of Anchorage Zone Reinforcement in Prestressed Concrete Beams," J. PCI, Vol. 12, No. 2, 1967, pp. 63 75.

11. Stone, W. C. and Breeen, J. E., "Design of Post-Tensioned Girder Anchorage Zones," J. PCI, Vol. 29, No. 2, 1984, pp. $28 \sim 61$.

12. Richard, M. B. and Puckett, J. A., Design of Highway Bridges, Chicago, Illinois, 1997.

13. Francis, J. J., "Study of Long Span Prestressed Concrete Bridge Girder," PCI Journal, Mar.-Apr., 1971, pp. 24 42.

14. Kathryn L. G., "Optimization of Precast/Prestressed Concrete Bridge I-Girder," MS thesis, University of Nebraska, Lincoln, 1992.

15. PCI Committee on Bridges, State-of-the-Art of Precast/ Prestressed Concrete Spliced I-Girder Bridges, 1995.

16. Mansur, M. A., Tan, K. H., and Wei W., "Effects of Creating an Opening in Existing Beams," ACI Structural Journal, Vol. 96, No. 6, 1999, pp. 899 905.

17. Ministry of Construction and Transportation, Korea Highway Bridge Design Specification, Korea, 2008.

18. Mindess, S., Young J. F., and Darwin, D., Concrete, Second Edition, Prentice Hall, 2003.

19. Stone, W. C. and Breeen, J. E., "Behavior of Post-Tensioned Girder Anchorage Zones," J. PCI, Vol. 29, No. 1, 1984, pp. $64 \sim 109$. 